\title{
DAMPAK PERCAYA DIRI DAN POWER LENGAN TERHADAP HASIL FLYING SHOOT DALAM PERMAINAN BOLA TANGAN
}

\author{
Indra Prabowo ${ }^{1 *}$ dan Davi Sofyan \\ Universitas Majalengka, Indonesia \\ indracoach07@yahoo.com,davisofyan@unma.ac.id
}

\begin{abstract}
ABSTRAK. Tujuan dari penelitian ini yaitu untuk mengetahui hubungan antara tingkat percaya diri dan power lengan terhadap hasil flying shoot dalam permainan bola tangan. Dalam penelitian ini sampel yang digunakan untuk kelompok eksperimen yaitu atlet SMA Se-Kota Bandung sebanyak 36 orang. Treatment yang akan dilakukan pada penelitian ini melakukan weight training yang akan dilakukan 12 kali pertemuan. Metode penelitian yang digunakan dalam penelitian ini adalah metode eksperimen dengan desain One-Group Pretest-Posttest Design. Teknik Analisis data dilakukan menggunakan statistik parametrik yang meliputi uji-t dan uji korelasi ganda menggunakan bantuan SPSS versi 20. Hasil penelitian menunjukkan bahwa percaya diri dan power lengan memiliki korelasi yang signifikan secara bersama-sama terhadap hasil flying shoot dalam permainan bola tangan yang dimana $r$ hitung sebesar 0,338 lebih besar dari $r$ tabel yaitu 0,329 .
\end{abstract}

Kata Kunci: Kepercayaan diri, Power lengan, Flying Shoot.

\section{Pendahuluan}

Pendidikan berawal saat seorang bayi baru lahir dan pendidikan dilakukan berlangsung seumur hidup. Pendidikan merupakan sebuah proses yang sangat panjang untuk menuju kehidupan yang lebih baik dalam berbagai aspek kehidupan. Pendidikan merupakan hal yang terpenting dalam kehidupan kita, ini berarti bahwa setiap manusia berhak mendapat dan berharap untuk selalu berkembang dalam pendidikan. Pendidikan secara umum mempunyai arti suatu proses kehidupan dalam mengembangkan diri tiap individu untuk dapat hidup dan melangsungkan kehidupan. Sehingga menjadi seorang yang terdidik itu sangat penting. Menurut UndangUndang No.20 Tahun 2003, tentang Sistem Pendidikan Nasional, bahwa: Pendidikan adalah usaha sadar dan terencana untuk mewujudkan suasana belajar dan proses latihan agar peserta didik secara aktif qaaqmengembangkan potensi dirinya untuk memiliki kekuatan spiritual keagamaan, pengendalian diri, kepribadian, kecerdasan, akhlak mulia, serta keterampilan yang diperlukan dirinya, masyarakat bangsa dan negara.

Pendidikan juga dapat diartikan sebagai proses memberikan atau mengtransfer ilmu dari generasi ke generasi lainnya. Ada berbagai aspek pendidikan yang menunjang kita untuk menjadi lebih baik dalam segala aspek kehidupan. Salah satunya ialah pendidikan olahraga. Pada masa sekarang olahraga sudah menjadi kebutuhan setiap lapisan masyarakat, baik untuk kesehatan bagi dirinya sendiri, hiburan, bahkan sebagai prestasi yang secara langsung berpengaruh terhadap gengsi sebuah negara. 
Berdasarkan hasil pengamatan di lapang, salah satu masalah dalam pelatihan adalah kurangnya percaya diri pada diri individu dalam menampilkan tugas gerak. Hal tersebut dapat dilihat pada saat proses latihan berlangsung. Terutama pada perempuan cenderung tidak mampu menampilkan tugas gerak yang diberikan dengan alasan tidak bisa, tidak berani, takut salah dan sebagainya.

Sejalan dengan Lauster dalam Ghufron (2010) menjelaskan bahwa kepercayaan diri diperoleh dari pengalaman hidup. Kepercayaan diri merupakan salah satu aspek kepribadian yang berupa keyakinan akan kemampuan diri seseorang sehingga tidak terpengaruh oleh orang lain dan dapat bertindak sesuai kehendak, gembira, optimis, cukup toleran dan bertanggung jawab. Sedangkan menurut Angelis dalam Umar (2011) menerangkan bahwa percaya diri merupakan suatu keyakinan dalam jiwa manusia untuk menghadapi tantangan hidup apapun dengan berbuat sesuatu.

Percaya diri merupakan faktor yang begitu penting bagi seseorang dalam menjalankan aktivitasnya, baik dalam kehidupan sehari-hari maupun berkehidupan sosial. Jika tanpa adanya rasa percaya diri, seseorang akan terus merasa takut untuk mencoba, takut untuk gagal, dan takut untuk salah. Hal ini menjadikan seseorang tidak berani untuk mengambil resiko dan lebih memilih diam tanpa mendapatkan pengalaman hidup yang baru. Menurut Husdarta (2010) mengungkapkan seperti halnya over confidence, lack confindence atau kurang percaya diri terhadap kemampuan diri dapat berakibat tidak baik. Seorang atlet yang memiliki lack confidence tidak akan mencapai tangga juara, karena sasaran atau target yang ditetapkan lebih rendah dari kemampuan yang dimilikinya.

Untuk mencapai pada tangga juara yang paling tinggi seseorang atlet harus full confidence, karena sikap mental seperti ini akan sangat membantu atlet dalam proses adaptasi menghadapi ketegangan yang berlebihan, memantapkan sendiri, dan menghindarkan atlet dari perasaan frustasi karena kegagalan. terutama percaya diri sangat dibutuhkan dalam setiap cabang olahraga. Dalam setiap kecabangan olahraga tentunya membutuhkan kekuatan dan kecepatan yang sering disebut dengan Power. Power merupakan salah satu komponen biomotorik yang memiliki peranan yang besar, untuk meningkatkan prestasi olahraga dan sangat diperlukan dalam berbagai cabang olahraga. Seorang atlet yang ingin berprestasi harus memiliki power yang baik. Power kadang kala disebut sebagai power eksplosif. Bompa dalam Himawanto (2010) membedakan power dalam dua jenis, yakni power asiklik dan power siklik. Pembedaan jenis power ini dilihat dari segi kesesuaian jenis latihan atau keterampilan gerak. Cabang-cabang olahraga yang memerlukan power asiklik secara dominan adalah melempar, menolak dan melompat pada pemain, unsur-unsur gerakan pada senam, bela diri, loncat 
indah, dan permainan. Sedangkan cabang-cabang olahraga seperti lari cepat, dayung, renang, bersepeda dan sejenisnya memerlukan power siklik yang dominan. Dari pendapat diatas maka unsur-unsur gerakan pada kecepatan melempar memerlukan jenis power asiklik yang dominan. salah satunya adalah cabang olahraga permainan bolatangan atau sering dikenal dengan Handball.

Olahraga permainan merupakan salah satu materi yang harus diikuti oleh siswa dalam proses latihan pendidikan jasmani, klasifikasi jenis olahraga permainan dapat digolongkan menjadi 4 jenis permainan yaitu Invasion, Net/Wall, Fielding/Run-Scoring dan Target. Hal ini sesuai dengan apa yang dikemukakan oleh Almond (1886) dalam Griffin et.al (1887) yang dikutip oleh Metzler (2001) yang mengatakan bahwa “...Kesemua jenis olahraga tersebut memiliki ciri-ciri pelaksanaan yang serupa, meski keterampilan teknik dasar yang berbedabeda. Klasifikasi system permainan yang serupa dari berbagai cabang olahraga terlihat dalam table 1 .

Tabel 1

Klasifikasi Sistem Permainan Berbagai Cabang Olahraga Almond (1886) dalam Griffin et.al (1887)

\begin{tabular}{|c|c|c|c|}
\hline Invasion & Net/Wall & Fielding/Run-scoring & Target \\
\hline Basketball & Badminton & Baseball & Golf \\
\hline TeamHandball & Volleyball & Softball & Croquet \\
\hline Water Polo & Tennis & Rounders & Bowling \\
\hline Soccer & Table Tennis & Cricket & Lawnbowls \\
\hline Hockey & Squash & Kickball & Pool \\
\hline Rugby & Pickle Ball & & Billiards \\
\hline Speedball & Racquetball & & Snookes \\
\hline Netball & Net & & \\
\hline Football & Fives & & \\
\hline
\end{tabular}

Dari tabel di atas dapat dijelaskan bahwa Invasion Games adalah permainan yang bertujuan untuk menguasai daerah lawan untuk membuat skor atau dapat diartikan sebagai permainan saling serang untuk memenangkan pertandingan. Net/Wall games melibatkan benda yang sengaja dilemparkan atau dipukul ke udara dengan tujuan untuk bisa dikembalikan oleh lawan bermainnya. Fielding/Run-scoring games tujuannya adalah untuk memukul suatu benda (biasanya bola) sehingga menghindarkannya dari penguasaan lawan. Target games diartikan sebagai permainan yang menuntut pelaku menggerakkan benda dengan tingkat ketepatan tinggi ke sasaran tertentu.

Dalam permainan bola tangan gerakan-gerakan dasar yang membangun pola gerak, dari mulai gerak lokomotor, gerak non lokomotor dan manipulative. Keterampilan gerakan dasar adalah hal penting yang nantinya dapat menunjang pengembangan keterampilan-keterampilan 
yang lebih kompleks. Dalam artikelnya Basic Introduction (2008) Euro Handball Federation kemudian disebut EHF, dalam memainkannya "Handball is a team sport played by two male or female teams. The players are allowed to handle and throw the ball using their hands, but they must not touch the ball with their feet". Arti dari pernyataan di atas, "bolatangan adalah permainan beregu yang dimainkan oleh dua tim putra atau putri. Para pemainnya diperbolehkan memegang dan melempar bola menggunakan tangannya, tetapi tidak boleh sampai menyentuhkan bola ke kaki”".

Dalam artikel yang sama basic introduction (2008) Tujuan permainan ini berupa"The objective of the game is to score and avoid getting goals. The team that scores more goals in a given period of time wins the match. "Tujuan dari permainan ini adalah untuk mencetak skor dan menghindari kemasukan. Tim dengan jumlah skor terbanyak hingga babak terakhir memenangkan pertandingan,"

\section{Metode Penelitian}

Metode penelitian yang digunakan dalam penelitian ini adalah metode eksperimen dengan desain One-Group Pretest-Posttest Design.

Keterangan:

$$
\mathrm{O}_{1} \times \mathrm{O}_{2}
$$

$\mathrm{O} 1=$ Nilai pretest sebelum di treatment

$\mathrm{O} 2=$ Nilai posttest setelah di treatment

Treatment yang akan dilakukan pada penelitian ini melakukan weight training yang akan dilakukan 12 kali pertemuan. Tidak hanya itu perlakuan treatment dilakukan juga dengan memperbaiki koordinasi dari teknik gerakan flying shoot itu sendiri yang dinyatakan Suharno dalam Himawanto (2010, hlm. 39) faktor-faktor penentu power salah satunya adalah koordinasi gerakan harmonis. Treatment untuk meningkatkan rasa percaya diri menurut Komarudin (2013) yaitu salah satunya melakukan latihan conditioning atau latihan fisik. Dalam penelitian ini sampel yang digunakan untuk kelompok eksperimen penelitian ini adalah Atlet SMA Bolatangan se-kota Bandung sebanyak 36 orang.

Instrumen yang digunakan dalam penelitian ini terbagi menjadi 2 hal utama yang mempengaruhi kualitas hasil penelitian, yaitu kualitas instrumen penelitian dan kualitas pengumpulan data. Dalam penelitian ini instrumen yang digunakan adalah tes softball throw untuk melihat power lengan, angket penilaian percaya diri dan flying shoot. Angket yang digunakan dengan membuat pernyataan dengan harapan dapat mengungkap isi hati responden yang diukur berdasarkan kisi-kisi dan prosedur yang benar, angket dalam penelitian ini terdiri 
atas komponen atau variabel yang dijabarkan melalui sub variabel, indikator-indikator dan pertanyaan. Butir- butir pertanyaan atau pernyataan tersebut merupakan gambaran tentang nilai kepercayaan diri yang dialami atlet SMA bola tangan Se-kota bandung dalam hasil flying shoot dalam permainan bola tangan.

\section{Hasil dan Pembahasan}

Telah dilakukan penelitian tentang dampak percaya diri dan power lengan terhadap hasil flying shoot dalam permainan bola tangan. Besar hubungan antara tingkat kepercayaan diri dan power lengan terhadap hasil flying shoot pada permainan bola tangan dapat terlihat dari besaran nilai korelasi ganda pada dua variabel. Nilai sig $\mathrm{F}$ change diperoleh nilai sebesar 0,136 dan $\mathrm{r}$ hitung sebesar 0,338 lebih besar dari $r$ tabel yaitu 0,329. $r$ hitung menunjukan bahwa $r$ hitung $>0,05$ maka kepercayaan diri dan power lengan mimiliki korelasi/berhubungan terhadap hasil flying shoot, seperti pada tabel 1. Selain itu dapat dilihat dari hasil uji signifikasi koefisien korelasi dengan menggunakan uji F pada data Paired Sampel Test dapat diketahui bahwa nilai Sig (2tailed) sebesar $0,000<0,05$, seperti pada tabel 2 .

Tabel 2. Hasil Perhitungan Korelasi Percaya Diri dan Power Lengan Secara Bersama-sama dengan Flying Shoot

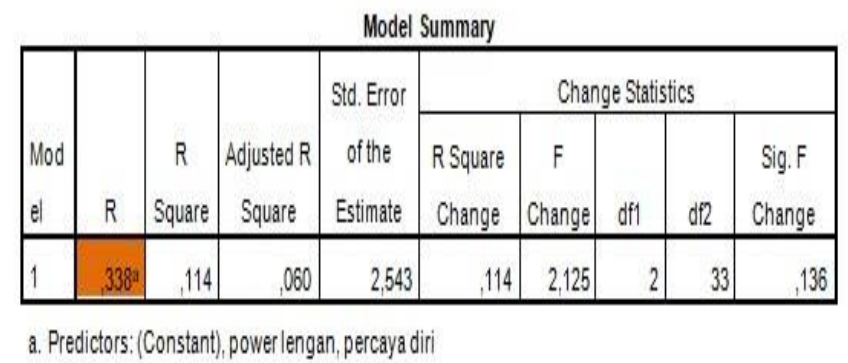

Tabel 3. Hasil Uji Signifikansi Koefisien Korelasi Percaya diri dan Power Lengan dengan Flying Shoot

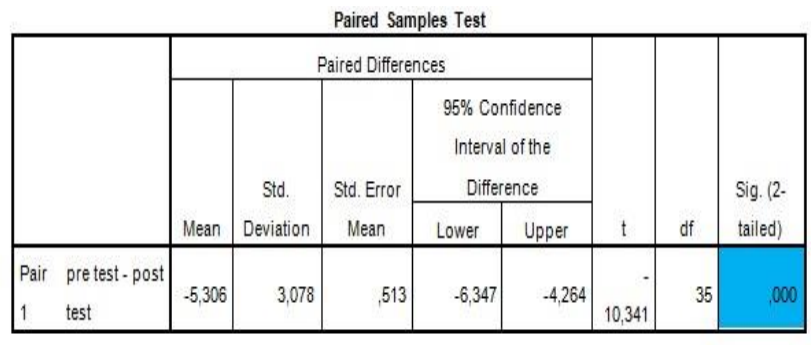

Oleh karena itu dapat disimpulkan bahwa tingkat kepercayan diri dan power lengan memiliki hubungan terhadap hasil flying shoot pada permainan bola tangan. Sehingga dari hasil ini dapat kita simpulkan bahwa terdapat kontribusi yang signifikan antara tingkat percaya diri dan power lengan secara bersama- sama terhadap hasil flying shoot. 


\section{Kesimpulan}

Berdasarkan hasil pengolahan dan analisis data diperoleh jawaban dari dua pertanyaan penelitian yang telah diajukan. Berikut merupakan jawaban sekaligus kesimpulan dari penelitian tentang dampak percaya diri dan power lengan terhadap hasil flying shoot dalam permainan bola tangan.

Terdapat hubungan antara tingkat percaya diri dan power lengan terhadap flying shoot pada permainan bola tangan. Berdasarkan Nilai sig $\mathrm{F}$ change diperoleh nilai sebesar 0,136 dan $\mathrm{r}$ hitung sebesar 0,338 lebih besar dari $r$ tabel yaitu 0,329. $r$ hitung menunjukan bahwa $r$ hitung $>$ 0,05 maka kepercayaan diri dan power lengan mimiliki korelasi/berhubungan terhadap hasil flying shoot.

Terdapat perbedaan yang signifikan antara tingkat percaya diri dan power lengan terhadap hasil flying shoot pada permainan bola tangan. Berdasarkan uji F pada data Paired Sampel Test dapat diketahui bahwa nilai Sig (2-tailed) sebesar $0,000<0,05$,

\section{Daftar Pustaka}

Arikunto, S. (2013). Prosedur Penelitian. Jakarta : PT. Rineka Cipta Jakarta

Mahendra, A. (2000). Bolatangan. DEPDIKBUD DIRJEN Pendidikan dasar dan Menengah.

Fatimah, E. (2006). Psikologi Perkembangan: Perkembangan Peserta Didik. Bandung: Balai Setia.

Ghufron, N \& Risnawati, R. (2010). Teori-Teori Psikologi. Yogyakarta : Ar-Ruzz Media Group.

Himawanto, W. (2010). Pengaruh Metode Latihan dan Power Lengan Terhadap Peningkatan Kecepatan Smash Bulutangkis. Jurnal 38-39

Husdarta. (2010). Psikologis. Bandung Alfabeta

Ibrahim, R. (2015). Psikologi Kepelatihan. Bandung: CV. Nurani.

Ishak, M. (2011). Kontribusi Daya Ledak Lengan, Kelentukan Pergelangan tangan dan Kelincahan Kaki Terhadap Pukulan Smash Dalam Permainan Bulutangkis Pada Siswa SMA Negeri 2 Bantaeng. Jurnal Competitor. 2, (3), 93-104

Komarudin. (2013). Psikologi Olahraga. Bandung: PT Remaja Rosdakarya

Lauster, P. (2008). Tes Kepribadian. Jakarta: Bumi Aksara.

Metzler, W. M. (2011). Instructional Models For Physcal Education Scottdale. Second Edition Arizona: Holcomb Hathawa.

Sugiyono. (2014). Metode Penelitian Kuantitatif dan Kualitatif. Bandung: Alfabeta.

Umar, T. (2011). Pengaruh Outbound Training Terhadap Peningkatan Rasa Percaya Diri Kepemimpinan dan Kerjasama Tim. Jurnal Ilmiah SPIRIT. 11,(3), 59-70.

Yulianto, F.,dan Nashori, H. F. (2006). Kepercayaan Diri dan Prestasi Atlet Taekwondo Daerah Istimewa Yogyakarta. Jurnal Psikologi. 3, (1), 55-62 